\title{
Care in a birth center according to the recommendations of the World Health Organization
}

\author{
ASSISTÊNCIA EM UM CENTRO DE PARTO SEGUNDO AS RECOMENDAÇÕES DA \\ ORGANIZAÇÃO MUNDIAL DA SAÚDE
}

\section{ATENCIÓN EN UN CENTRO DE PARTO SEGÚN LAS RECOMENDACIONES DE LA ORGANIZACIÓN MUNDIAL DE LA SALUD}

\section{Flora Maria Barbosa da Silva1, Taís Couto Rego da Paixão², Sonia Maria Junqueira Vasconcellos de Oliveira $^{3}$, Jaqueline Sousa Leite ${ }^{4}$, Maria Luiza Gonzalez Riesco ${ }^{5}$, Ruth Hitomi Osava ${ }^{6}$}

\begin{abstract}
Birth centers are maternal care models that use appropriate technology when providing care to birthing women. This descriptive study aimed to characterize intrapartum care in a freestanding birth center, in light of the practices recommended by the World Health Organization (WHO), with 1,079 assisted births from 2006 to 2009 in the Sapopemba Birth Center, São Paulo, Brazil. Results included the use of intermittent auscultation (mean=7 controls); maternal positions during delivery: semi-sitting $(82.3 \%)$, side-lying $(16.0 \%)$, other positions $(1.7 \%)$, oral intake (95.6\%); companionship (93.3\%); exposure to up to three vaginal examinations $(85.4 \%)$, shower bathing $(84.0 \%)$, walking $(68.0 \%)$, massage $(60.1 \%)$, exercising with a Swiss ball (51.7\%); amniotomy (53.4\%), oxytocin use during the first $(31.0 \%)$ and second stages of labor (25.8\%), bath immersion (29.3\%) and episiotomy (14.1\%). In this birth center, care providers used practices recommended by the WHO, although some practices might have been applied less frequently.
\end{abstract}

\section{DESCRIPTORS}

Parturition

Natural childbirth

Obstetrical nursing

Birthing Centers

\section{RESUMO}

Centros de parto constituem modelo que adota tecnologia apropriada na assistência à parturiente. $\mathrm{O}$ objetivo foi caracterizar a assistência intraparto em um centro de parto extra-hospitalar quanto às práticas recomendadas pela Organização Mundial da Saúde (OMS). Estudo descritivo sobre 1.079 partos assistidos de 2006 a 2009 na Casa do Parto de Sapopemba, São Paulo, Brasil. Os resultados mostraram ausculta intermitente (média=7 controles); posição materna no expulsivo semissentada $(82,3 \%)$, lateral $(16,0 \%)$, outras $(1,7 \%)$; aceitação da dieta (95,6\%); acompanhante $(93,3 \%)$; até três exames vaginais $(85,4 \%)$; banho de aspersão $(84,0 \%)$, deambulação $(68,0 \%)$, massagem $(60,1 \%)$, exercícios com bola suíça $(51,7 \%)$; amniotomia $(53,4 \%)$; ocitocina na dilatação $(31,0 \%)$, banho de imersão $(29,3 \%)$, ocitocina no expulsivo $(25,8 \%)$ e episiotomia $(14,1 \%)$. Concluiu-se que os profissionais do centro de parto utilizam práticas recomendadas pela OMS, contudo existem práticas cujo uso pode ser reduzido, tais como amniotomia, administração de ocitocina, episiotomia e posição semissentada no expulsivo.

DESCRITORES
Parto
Parto normal
Enfermagem obstétrica
Centros Independentes de Assistência a
Gravidez e ao Parto

\section{RESUMEN}

Centros de parto constituyen un modelo que adopta la tecnología apropiada en la atención a la parturienta. El objetivo fue caracterizar la atención intraparto en un centro de parto extra-hospitalario en relación a las prácticas recomendadas por la Organización Mundial de la Salud (OMS). Estudio descriptivo sobre 1.079 partos atendidos del 2006 al 2009 en la Casa de Parto de Sapopemba, São Paulo, Brasil. Los resultados mostraron: auscultación intermitente (media=7 controles); posición materna en el expulsivo - semisentada $(82,3 \%)$, lateral $(16,0 \%)$, otras $(1,7 \%)$; aceptación de dieta $(95,6 \%)$; acompañante $(93,3 \%)$; hasta tres exámenes vaginales $(85,4 \%)$; baño en ducha $(84,0 \%)$, deambulación $(68,0 \%)$, masaje $(60,1 \%)$, ejercicios con pelota suiza $(51,7 \%)$; amniotomía $(53,4 \%)$; oxitocina durante la dilatación (31,0\%), baño de inmersión $(29,3 \%)$, oxitocina durante el expulsivo $(25,8 \%)$ y episiotomía $(14,1 \%)$. Se concluyó que los profesionales del centro de parto utilizan prácticas recomendadas por la OMS, pero existen algunas prácticas cuyo uso puede reducirse, tales como la amniotomía, administración de oxitocina, episiotomía y posición semisentada en el período expulsivo.

DESCRIPTORES
Parto
Parto normal
Enfermería obstétrica
Centros Independientes de Asistencia al
Embarazo y al Parto

${ }^{1}$ Nurse Midwife. Senior Lecturer in the Midwifery Course, School of Arts, Sciences and Humanities, University of São Paulo. São Paulo, Brazil. floramaria@ usp.br ${ }^{2}$ Nurse. Pedreira General Hospital. São Paulo, Brazil. taiscoutorp@gmail.com ${ }^{3}$ Nurse Midwife. Associate Professor, Maternal-Child and Psychiatric Nursing Department, School of Nursing, University of São Paulo. São Paulo, Brazil. soniaju@usp.br ${ }^{4}$ Nurse Midwife. Master Candidate, Graduate Program, School of Nursing, University of São Paulo. São Paulo, Brazil. jaquelinesousa26@hotmail.com ${ }^{5}$ Nurse Midwife. Associate Professor, Maternal-Child and Psychiatric Nursing Department, School of Nursing, University of São Paulo. São Paulo, Brazil. riesco@usp.br ${ }^{6}$ Nurse Midwife. Senior Lecturer in the Midwifery Course, School of Arts, Sciences and Humanities, University of São Paulo. São Paulo, Brazil. rosava@usp.br

Rev Esc Enferm USP 2013; 47(5):1031-8 www.ee.usp.br/reeusp/ 


\section{INTRODUCTION}

In Brazil, several changes have influenced the care provided to women during pregnancy and childbirth. Access to higher levels of education, urbanization, increased participation of women in the labor market and lower birth rates combined with better access to antenatal and intrapartum care, have positively affected maternal health indicators ${ }^{(1)}$. Notwithstanding, the overuse of several interventions, mainly in birth-assisted hospitals, such as frequent ultrasound examinations during pregnancy and high rates of $\mathrm{C}$-sections in complementary health services represent remaining challenges. In the Brazilian Health System (SUS) services, episiotomies and intravenous administration of oxytocin are also often routinely used during intrapartum care ${ }^{(1-2)}$.

Paradoxically, while the justification for using these more invasive and aggressive procedures is to provide effective care and safety for the mother and her newborn, data suggest that the use of oxytocin, ultrasounds and Csections may in fact be associated with poorer maternal and neonatal outcomes. A 2008 cohort study in Pelotas (Rio Grande do Sul, Brazil) demonstrated that the increase in C-sections and labor inductions over the last three decades has resulted in a higher number of preterm or low birth weight babies ${ }^{(3)}$.

As a reaction against this model of care, a movement initiated by public health professionals sought to change the paradigms of Brazilian obstetrical care. One of the pillars of this movement was an analysis of the risks and benefits of obstetric practices presented by a group of European experts, which resulted in the publication known as the recommendations of the World Health Organization (WHO). This guide classifies practices into four categories:

\footnotetext{
A: practices which are demonstrably useful and should be encouraged; B: practices which are clearly harmful or ineffective and should be eliminated; C: Practices for which insufficient evidence exists to support a clear recommendation and which should be used with caution while further research clarifies the issue; and $\mathrm{D}$ : Practices which are frequently used inappropriately(4).
}

In Brazil, these recommendations have been used as guidelines for programs whose aim is to humanize the care given during the normal birthing process and are outlined in a guidebook distributed by the Ministry of Health to all obstetric healthcare professionals in the country ${ }^{(5)}$. In this guidebook, the classification of practices has been updated, and some practices have been listed in a different category. The liberal or routine use of episiotomy, for instance, was moved from category $D$ to category $B$ (the latter category is identified as 2 in the Ministry of Health guidebook).
In addition to influencing the type of care provided to women and babies, the humanization movement has impacted how women are assisted during labor. By the late 1990s, Birth Centers (BC) were created and, under the regulation of Ordinance $985 / 99^{(6)}$, they aimed to provide obstetric care with the appropriate use of technology while also valuing childbirth as a normal physiological and family centered event. These services have been disseminated throughout Brazil and are part of the proposed Stork Network, an initiative of the Ministry of Health that was established in 2011 to ensure improved access, coverage and quality of maternal and neonatal $\operatorname{care}^{(7)}$.

However, few Brazilian studies have described the care provided exclusively by nurse-midwives and midwives in the BC. These professionals are generally in charge of providing care to women during childbirth in healthcare settings and are entrusted to make judicious use of obstetric interventions. Therefore, it is important to evaluate whether these professionals are using evidence-based practices that are recommended by the WHO in caring for women and their newborns during childbirth. Moreover, new studies may help to improve the criteria utilized by these centers and may provide information for women seeking an out-of-hospital environment to in which to give birth.

Within this context, this study aimed to characterize intrapartum care in a freestanding $B C$ in light of the practices recommended by the WHO.

\section{METHOD}

This is a descriptive study with a retrospective data collection that was performed in the Sapopemba Birth Center (SBC), which has the Vila Alpina State Hospital as the referral center. This BC is located in the southeast of the city of São Paulo, Brazil.

The study participants were all women who gave birth in the SBC between 2006-2009, for a total of 1,079 births. Data were obtained by retrospective manual collection, using a pre-coded form, named CPNet. This instrument has been part of the maternal records of the SBC since 2006 and is completed by the nurse-midwives and midwives who attend the birth.

The variables were categorized into the following categories: demographic data (age, education, skin color, marital status, employment status, origin, and coverage area); clinical obstetric characteristics (number of previous births, cervical dilation at the time of admission, status of membranes on admission, gestational age, and uterine activity); characteristics of the intrapartum care (mode of rupture of membranes, oxytocin use, fetal electronic monitoring, frequency of evaluation of uterine activity and frequency of vaginal examinations, oral intake, practices to provide comfort and pain relief during labor, maternal position at
Care in a birth center according to the recommendations of the World Health Organization Silva FMB, Paixão TCR, Oliveira SMJV, Leite JS, Riesco MLG, Osava RH 
delivery, condition of the perineum, removal of the placenta and companionship during labor) and characteristics of the newborn care (airway aspiration, gastric aspiration and washing, use of inhaled oxygen and Apgar scores).

These data were double entered into a database. A descriptive analysis of the data was performed to calculate the absolute and relative frequencies of the categorical variables that are presented in the tables or the text. We used the statistical package STATA version 17. This study is part of the project Maternal and neonatal transfers from the Sapopemba Birth Center and was approved by the Research Ethics Committee of the Municipal Health Department (Process number 223/2006/CEP/SMS).

\section{RESULTS}

During the four years of the study, 1,079 births were assisted in the Sapopemba Birth Center. Less than $20 \%$ of women were adolescents, and more than $70 \%$ of them had eight or more years of schooling. Most of the participants were white, had a partner, were employed, spontaneously sought the service in order to give birth and belonged to the area of the SBC (Table 1).

Table 1 - Distribution of women according to the sociodemographic characteristics. Sapopemba Birth Center, São Paulo, SP, Brazil, 2006-2009

\begin{tabular}{|c|c|c|}
\hline Characteristics & $\mathbf{F}$ & $\%$ \\
\hline \multicolumn{3}{|l|}{ Age group (years) } \\
\hline$\leq 19$ & 189 & 17,5 \\
\hline 20 a 24 & 397 & 36,8 \\
\hline 25 a 29 & 307 & 28,5 \\
\hline 30 a 34 & 133 & 12,3 \\
\hline 35 a 39 & 43 & 4,0 \\
\hline$\geq 40$ & 10 & 0,9 \\
\hline \multicolumn{3}{|l|}{ Schooling (years) } \\
\hline 1 a 7 & 250 & 23,2 \\
\hline 8 a 11 & 712 & 66,0 \\
\hline$>11$ & 113 & 10,5 \\
\hline None & 4 & 0,4 \\
\hline \multicolumn{3}{|l|}{ Skin color } \\
\hline White & 652 & 60,4 \\
\hline Non-white & 427 & 39,6 \\
\hline \multicolumn{3}{|l|}{ Marital status } \\
\hline With partner & 994 & 92,1 \\
\hline No partner & 85 & 7,9 \\
\hline \multicolumn{3}{|l|}{ Employment } \\
\hline No & 400 & 37,1 \\
\hline Yes & 679 & 62,9 \\
\hline \multicolumn{3}{|l|}{ Origin of the woman } \\
\hline Spontaneous search & 649 & 60,2 \\
\hline Referred from the primary care unit & 295 & 27,3 \\
\hline Previous birth in the SBC & 135 & 12,5 \\
\hline \multicolumn{3}{|l|}{ Coverage area } \\
\hline Yes & 743 & 68,9 \\
\hline No & 336 & 31,1 \\
\hline
\end{tabular}

During the period of prenatal care, 942 women (87.3\%) had six or more appointments and completed all prenatal appointments made at public, private or insured care covenants, and 709 (65.7\%) had at least three appointments at the SBC. Thirty-eight women (3.5\%) had antepartum complications during pregnancy, such as leucorrhoea and urinary tract infections, for which they were treated. Of the 1,079 pregnant women, $991(91.8 \%)$ were users of the National Health System (SUS), and 88 (8.2\%) received private or insured health care.

Most women admitted to the SBC had already had one or more previous deliveries. Half of the women were 5 or more centimeters dilated; most had intact membranes and were full-term and in active labor. These data refer to the condition of the women during the obstetric admissions examination in the SBC (Table 2). Among those with previous births, 571 (52.9\%) had had normal deliveries, 18 (1.7\%) had necessitated forceps, and 19 (1.8\%) had C-sections.

Table 2 - Distribution of women according to the clinical and obstetric characteristics at the time of admission to the SBC. Sapopemba Birth Center, São Paulo, SP, Brazil, 2006-2009

\begin{tabular}{lcc}
\hline Clinical and obstetric characteristics & F & \% \\
\hline Previous deliveries & 493 & 45,7 \\
0 & 313 & 29,0 \\
1 & 153 & 14,2 \\
2 & 120 & 11,1 \\
$\geq 3$ & & \\
Cervical dilation (cm) & 540 & 50,0 \\
0 a 4 & 510 & 47,3 \\
5 a 9 & 29 & 2,7 \\
10 & & \\
Condition of the placental membranes & 790 & 73,2 \\
Íntact & 289 & 26,8 \\
Broken & & \\
Gestational age (weeks) & 3 & 0,3 \\
$<37$ & 1074 & 99,5 \\
37 a 41 & 2 & 0,2 \\
$>41$ & & \\
Uterine activity & 971 & 90,0 \\
Yes & 108 & 10,0 \\
No & & \\
\hline Note: (n= 1.079) & & \\
&
\end{tabular}

Regarding the maternity care practices used during the intrapartum period, most women had artificial rupture of the membranes. Approximately a third of the women received intravenous oxytocin for augmentation of labor, and a quarter of the women received oxytocin in the second stage of labor. During labor, slightly more than a quarter of the women had electronic monitoring for fetal assessment. Most of the women used non-pharmacological methods of pain relief and comfort, accepted food during labor and had a companion present (Table 3). Intermittent auscultation of the fetal heart was performed on average 7 times for each woman. 
Table 3 - Distribution of intrapartum maternity care practices in the SBC. Sapopemba Birth Center, São Paulo, SP, Brazil, 2006-2009

\begin{tabular}{|c|c|c|}
\hline Maternity care practices & $\mathbf{F}$ & $\%$ \\
\hline \multicolumn{3}{|c|}{ Rupture of the placental membranes } \\
\hline Artificial & 576 & 53,4 \\
\hline aSpontaneous & 503 & 46,6 \\
\hline \multicolumn{3}{|l|}{${ }^{\mathrm{b}}$ Oxytocin use } \\
\hline Dilation phase & 334 & 31,0 \\
\hline Expulsive phase & 278 & 25,8 \\
\hline Placental expulsion phase & 228 & 21,1 \\
\hline 1st hour after birth & 261 & 24,2 \\
\hline \multicolumn{3}{|l|}{ Fetal electronic monitoring } \\
\hline Yes & 301 & 27,9 \\
\hline No & 778 & 72,1 \\
\hline \multicolumn{3}{|l|}{ Uterine activity assessment } \\
\hline 0 & 35 & 3,2 \\
\hline 1 & 494 & 45,8 \\
\hline 2 & 267 & 24,8 \\
\hline$\geq 3$ & 283 & 26,2 \\
\hline \multicolumn{3}{|c|}{ Number of vaginal examinations } \\
\hline 1 & 126 & 11,7 \\
\hline 2 & 403 & 37,4 \\
\hline 3 & 393 & 36,4 \\
\hline$\geq 4$ & 157 & 14,5 \\
\hline \multicolumn{3}{|l|}{ Oral intake } \\
\hline No & 47 & 4,4 \\
\hline \multicolumn{3}{|l|}{ Yes } \\
\hline Fluids & 421 & 39,0 \\
\hline Fluids and solid food & 611 & 56,6 \\
\hline \multicolumn{3}{|c|}{ 'Pain relief and comfort practices } \\
\hline Shower bath & 906 & 84.0 \\
\hline Walking & 734 & 68,0 \\
\hline Massage & 648 & 60,1 \\
\hline Swiss ball & 558 & 51,7 \\
\hline Immersion bath & 316 & 29,3 \\
\hline \multicolumn{3}{|l|}{ Companionship } \\
\hline Yes & 1.020 & 94,5 \\
\hline No & 59 & 5,5 \\
\hline
\end{tabular}

a213 women admitted in the SBC with ruptured membranes were also included

${ }^{b}$ Oxytocin was used during one or more phases of labor

'One or more pain relief or comfort practices were used by the birthing women Note: $(n=1.079)$

Most of the women adopted a semi-sitting position when giving birth, and maneuvers to remove the placenta were not required. More than $70.0 \%$ of the women had an intact perineum after delivery or had minor first-degree lacerations (Table 4). An episiotomy was performed in $25.8 \%$ of nulliparous and in $4.3 \%$ of multiparous women.

Regarding neonatal practices, warm fields and early skin-to-skin mother-child contact were used to prevent hypothermia. Among the newborns assisted in the SBC, $75(7.0 \%)$ required airway aspiration, $40(3.7 \%)$ required gastric aspiration, $30(2.3 \%)$ required gastric lavage, and 60 (5.6\%) required inhaled oxygen. Most of the neonatal Apgar scores were equal to or higher than 7 at the 1st and 5th minutes of life (1070 - 99.2\% and 1079 - 100\%, respectively). Eight women $(0.7 \%)$ and 21 newborns $(2.0 \%)$ were transferred to the referral hospital.
Table 4 - Distribution of the maternity care practices used during the second stage of labor and the removal of the placenta in the SBC. Sapopemba Birth Center, São Paulo, SP, Brazil, 2006-2009

\begin{tabular}{lcc}
\hline Maternity care practices & F & \% \\
\hline Maternal position in the expulsive phase & & \\
Semi-sitting & 888 & 82,3 \\
Side-lying & 173 & 16,0 \\
Squatting & 9 & 0,8 \\
All-fours & 2 & 0,2 \\
Standing & 7 & 0,7 \\
Perineal condition & & \\
Intact & 471 & 43,7 \\
1st degree laceration & 344 & 31,9 \\
2nd degree laceration & 111 & 10,3 \\
3rd degree laceration & 1 & 0,1 \\
Right mediolateral episiotomy & 139 & 12,9 \\
Median episiotomy & 13 & 1,2 \\
Placental delivery & & \\
Spontaneous & 1057 & 98,0 \\
Manual removal & 22 & 2,0 \\
\hline Note: (n=1.079) & &
\end{tabular}

Note: $(\mathrm{n}=1.079)$

The following practices were not used in the SBC: enemas, perineal shaving, routine insertion of an intravenous catheter, routine oxytocin use, rectal examination, use of $X$-ray pelvimetry, pain control by epidural anesthesia and systemic agents, fundal pressure (maneuver Kristeller), routine use of the supine position during labor, shortening of the $2^{\text {nd }}$ stage of labor if the recommended duration (one hour) is exceeded, early clamping of the umbilical cord, use of ergometrine in the third stage, washing and examination of the uterus after the delivery.

A partograph was used to register the progress of labor for all women in the SBC. The sustained breath-holding (Valsalva) method of pushing, management of the perineum during the second stage of labor and controlled traction on the umbilical cord were all eventually performed. However, these practices were not investigated in this study.

All of the material used during the deliveries was sterilized according to the sterilization and decontamination protocols used for hospital supplies. Standardized guidelines for universal precautions were used during all interactions with the mother and the newborn.

\section{DISCUSSION}

This study investigated the care offered to women and their newborns in a freestanding birth center according to the WHO recommendations on maternal and neonatal care practices. Not all of the women attending the SBC come from the geographical area covered by the service, which suggests that this type of assistance has attracted women from other areas of the city of São Paulo. The proportion of women assisted in the SBC with eight or more years of schooling was similar to that found in another study on BC
Care in a birth center according to the recommendations of the World Health Organization Silva FMB, Paixão TCR, Oliveira SMJV, Leite JS, Riesco MLG, Osava RH 
performed in Brazil. The proportion of nullipara assisted in the SBC was similar to those observed in the present this study $(46.0 \%)^{(8)}$.

Discussion of the practices used in the care offered to women and newborns in the SBC is presented according to the categories $A, C$ and $D$ that have been proposed by the WHO. No practice used in the service was classified in Category B (Practice clearly harmful or ineffective and should be eliminated).

\section{Category A}

The birthing woman care protocol in the SBC included appointments from 37 weeks of pregnancy, at which time obstetric and clinical risk factors were assessed based on the individual birth plan. This assessment was performed and documented on an ongoing basis for all women, i.e. at the time of admission, throughout labor and during the postpartum period. Although the birth plan in SBC primarily involved an assessment for the purpose of risk classification, this instrument was also used to register women's preferences for the care they received during labor and delivery. Moreover, the involvement of the health service users has been recommended in the clinical decision making process during labor and delivery ${ }^{(9)}$.

Ninety four percent of women in the SBC had companionship during labor. This rate is similar to that of the $B C$ study, which reported a companionship rate of $92.2 \%^{(10)}$. These rates are higher than those reported in a national survey, in which the verifiable presence of a companion was noted in $16.0 \%$ of the deliveries in general, which is less than $\mathbf{1 0 . 0 \%}$ for women assisted in the SUS and 35.0 $\%$ for those in the private sector ${ }^{(11)}$. A study conducted in 13 hospitals in the city of Goiânia, Brazil, found that $19.5 \%$ of women had a companion present during labor ${ }^{(12)}$. In the Philippines and Malaysia, one study reported that a companion was present during labor in $10.0 \%$ and $61 \%$ of deliveries, respectively ${ }^{(13)}$. A study that examined the care practices in hospitals in Jordan reported that a companion was present during approximately $1.0 \%$ of deliveries ${ }^{(14)}$.

The importance of the presence of a companion during labor was confirmed in a systematic review that included 22 clinical trials with 15,288 women. The presence of continuous intrapartum support increased the probability of a faster labor and spontaneous vaginal delivery and was associated with a decreased likelihood of intrapartum analgesia, instrumental delivery and C-section, a low Apgar score at the 5th minute of life and dissatisfaction with the birth experience ${ }^{(15)}$.

Among the pain relief practices used, the shower bath was the most utilized, though the phase of labor during which this method was used was not specified. Similar data were found in Brazil, where up to $71.0 \%$ of birthing women used the shower bath in an alongside birth center ${ }^{(10)}$ and $88.0 \%$ of those assisted in an in-hospital center ${ }^{(16)}$. In a study from Jordan, additional care practices used to minimize the discomfort associated with uterine contractions included changes in maternal position (3.0\%), back massage $(2.0 \%)$ and therapeutic touch $(1.0 \%)^{(14)}$.

Intermittent auscultation of the fetal heart was the method of choice for monitoring fetal wellbeing during labor in the SBC. A systematic review involving 18,561 pregnant women and their 18,695 infants compared the use of continuous cardiotocography with no fetal monitoring, intermittent auscultation and intermittent cardiotocography and found no difference in the overall rate of perinatal death between these methods of fetal monitoring ${ }^{(17)}$.

Most women who gave birth in the SBC walked during labor (68.0\%), which is a rate lower than that found in a Brazilian study in which $88.0 \%$ of the women used this practice. In contrast, the aforementioned Jordanian study reported that $94.0 \%$ of women were restricted to the bed $^{(14)}$.

In a systematic review involving 3,706 women, those who adopted the upright vs. lying down position shortened the active phase of labor by one hour. These women were also less likely to receive epidural anesthesia, with no differences noted in the second stage of labor or in the mode of delivery and no impairment of maternal and fetal well-being ${ }^{(18)}$. In a study conducted in 29 hospitals in Malaysia with 280 women, $79.3 \%$ of the women were informed about the positions for childbirth, and $83.4 \%$ chose a position other than supine ${ }^{(19)}$. The present study revealed that most women in the SBC adopted the semi-sitting position during the second stage of labor.

Oxytocin was used at the discretion of the nurse-midwife and generally only in women with risk factors for post-partum hemorrhage, such as multiparity, macrosomia and prolonged labor, among other situations. Approximately one third of women in the $\mathrm{SBC}$ received oxytocin, representing a higher rate than that found in a freestanding birth center $(23.5 \%)^{(10)}$ though lower than those found in hospitals $(45.8 \%)^{(12)}$. The practice of breastfeeding infants immediately after the delivery, which was systematically adopted in the SBC, is a measure that prevents postpartum hemorrhage.

\section{Category C}

The immersion bath, with or without whirlpool, was used by $29.3 \%$ of women. A systematic review of 3,243 women suggested that the use of this practice during the first stage of labor reduced the use of epidural anesthesia, with no adverse effects to either the mother or baby. The immersion bath was also associated with greater satisfaction with the childbirth experience ${ }^{(20)}$.

Amniotomy, or artificial rupture of placental membranes, was performed in $53.4 \%$ of women, which is a finding similar to the aforementioned study that was performed in an in-hospital birth center $(55.2 \%)^{(16)}$. In another study from our institution, this practice was used in $62.6 \%$ of women ${ }^{(10)}$. A study that examined the maternal and 
neonatal outcomes of an alongside birth center and an in-hospital birth center found that amniotomy rates were significantly lower in the former setting (71.3\%) compared to the latter setting $(84.5)^{(8)}$. Indications for performing amniotomy in the SBC were not assessed.

Despite the fact that perineal and fetal head management practices during the second stage of labor were not quantified in the present study, reports from SBC professional staff indicated that these maneuvers were used in some cases. A randomized clinical trial conducted in Iran compared the effect of two types of perineal management (hands on and hands poised) on perineal trauma in nulliparous women. The women in the group in which the hands on technique for perineal protection was used had twice as many episiotomies compared to women in the other group ( $84.0 \%$ vs. $40.0 \%$, respectively) $)^{(21)}$. However, further studies are needed to confirm these findings. One systematic review found that the decrease noted in the rate of episiotomy did not encompass third and fourth degree lacerations $^{(22)}$.

\section{Category D}

Cardiotocography was routinely performed on admission for all women in the SBC, most likely because all of the nurse-midwives had previous professional experience in hospitals. This record also served as documentation of fetal well-being at the time of admission.

A statistically significant association has been reported between the use of fetal electronic monitoring (FEM) and the decrease of neonatal seizures. No significant difference was observed in the one minute Apgar (with scores between 4 and 7), the rates of admissions to neonatal intensive care units, perinatal deaths or cerebral palsy rates. An increase in forceps and C-section delivery rates was associated with continuous FEM $^{(17)}$. Intermittent FEM was also used in the SBC, though the reasons for its use during labor were not assessed. SBC staff members reported prolonged labor and the need for documentation of fetal well-being as the reason for this examination, before transferring the woman from the SBC to the hospital.

The recommended interval between vaginal examinations varied from between one to four hours ${ }^{(4)}$. In the SBC, the interval between these examinations was not measured. However, $85.5 \%$ of the women were examined between one to three times during the intrapartum period.

Nearly $30.0 \%$ of the women in the SBC received oxytocin during labor, a finding which is higher than that found in an alongside BC (23.6\%) and lower than that in an in-hospital BC $(47.2 \%)^{(8)}$. Higher rates were reported in hospitals in Goiânia, Brazil, during labor (45.8\%) and delivery $(53.5 \%)^{(12)}$.

The rate of episiotomy in the current study was $14.1 \%$, with approximately one quarter of the women receiving an episiotomy and $43.7 \%$ sustaining an intact perineum during birth. A study in Asian countries revealed that episiotomy rates during vaginal deliveries were between $31.0 \%$ and $95.0 \%$ among the evaluated hospitals ${ }^{(13)}$. A Brazilian study reported an episiotomy rate of approximately $70.0 \%$. In contrast, in Jordan, $53.0 \%$ of women who had a vaginal delivery underwent an episiotomy, and of these women, $76.0 \%$ were primiparous ${ }^{(23)}$. A longitudinal study that followed nulliparous women with a history of a previous episiotomy found it to be an independent risk factor for receiving another episiotomy: Odds Ratio (OR) 2.84, 95\% confidence interval $(\mathrm{Cl}) 1.62$ to 4.99 as well as perineal lacerations in the following births $(59.2 \% \text { versus } 23.4 \%, p<0.05)^{(24)}$.

A systematic review on episiotomy that included 5,541 women noted that the restricted use of episiotomy resulted in less severe perineal trauma: RR (relative risk) 0.67 , $95 \% \mathrm{Cl} 0.49$ to 0.91 ; less suturing (RR $0.71 ; 95 \% \mathrm{Cl} 0.61$ to 0.81 ) and fewer healing complications (RR $0.69,95 \% \mathrm{Cl}$ 0.56 to 0.85$)$. There was no difference in the occurrence of severe vaginal trauma ( $\mathrm{RR} 0.9295 \% \mathrm{Cl} 0.72$ to 1.18), dyspareunia ( $R R \quad 1.02,95 \% \mathrm{Cl} 0.90$ to 1.16 ) and urinary incontinence (RR $0.98,95 \% \mathrm{Cl} 0.79$ to 1.20 ). However, restricting the use increased the risk of anterior perineal trauma, which was generally not clinically significant ${ }^{(25)}$.

In summary, no current scientific evidence supports the routine use of episiotomy, although in Brazil this procedure is still commonly performed. The difficulty surrounding the incorporation of evidence-based guidelines into clinical practice is not only evident with the persistent use of episiotomy, but is also seen in the management of perineal trauma. This phenomenon was highlighted in a cross-sectional study of British midwives who reported difficulties identifying and repairing perineal trauma ${ }^{(26)}$.

The retrospective data collection in this study did not allow for the evaluation of women's opinions about the care received during labor and childbirth. However, studies in which postpartum women were interviewed revealed that a lower level of interventionist care is associated with greater satisfaction with the birth experience $^{(15,27)}$ as well as enhancing the autonomy of nursemidwives and midwives ${ }^{(28)}$.

A limitation of this study is that the research results were compared with those obtained from national and international studies that evaluated practices in alongside and in-hospital birth centers and not with those in freestanding birth centers. It is also known that health services in which professionals support the physiological process of childbirth have lower rates of intervention(4), but this study did not aim to explore the differences between different birth settings, i.e. birth center, hospital and home births.

\section{CONCLUSION}

This analysis of the maternal care practices in the SBC revealed that the WHO recommendations are commonly used by the SBC staff. The judicious and non-routine use of interventions such as oxytocin, episiotomy and
Care in a birth center according to the recommendations of the World Health Organization Silva FMB, Paixão TCR, Oliveira SMJV, Leite JS, Riesco MLG, Osava RH 
resuscitation of the newborn are in line with scientific evidence, thus indicating that birth centers not connected with surgical environments. Furthermore, in environments where nurse-midwives and midwives are in charge of maternal care, maternal and perinatal outcomes are good as measured by the low rate of maternal and neonatal transfers and the good condition of the newborn.

\section{REFERENCES}

1. Victora CG, Aquino EM, Leal MC, Monteiro CA, Barros FC, Szwarcwald CL. Maternal and child health in Brazil: progress and challenges. Lancet. 2011;377(9780): 1863-76.

2. Brasil. Ministério da Saúde, Secretaria de Vigilância em Saúde. Saúde Brasil 2008: 20 anos do Sistema Único de Saúde (SUS) no Brasil [Internet]. Brasília; 2009 [citado 2012 set. 20]. Disponível em: http://portal.saude.gov.br/portal/arquivos/pdf/ saude_brasil_2008_web_20_11.pdf

3. Barros FC, Victora CG, Matijasevich A, Santos IS, Horta BL, Silveira MF, et al. Preterm births, low birth weight, and intrauterine growth restriction in three birth cohorts in Southern Brazil: 1982, 1993 and 2004. Cad Saúde Pública. 2008;24 Suppl 3:S390-8.

4. Worl Health Organization, Department of Reproductive Health \& Research. Care in normal birth: a practical guide [Internet]. Geneva; 1996 [cited 2012 Sept 20]. Available from: http:// whqlibdoc.who.int/hq/1996/WHO_FRH_MSM_96.24.pdf

5. Brasil. Ministério da Saúde, Secretaria de Políticas de Saúde. Parto, aborto e puerpério: assistência humanizada à mulher [Internet]. Brasília; 2001[citado 2013 mar. 12]. Disponível em: http://bvsms.saude.gov.br/bvs/publicacoes/cd04_13.pdf

6. Brasil. Ministério da Saúde. Portaria n. 985/GM, de 05 de agosto de 1999. Cria o Centro de Parto Normal-CPN, no âmbito do Sistema Único de Saúde [Internet]. Brasília; 1999 [citado 2013 mar. 12] Disponível em: http://dtr2001.saude.gov.br/ sas/PORTARIAS/Port99/GM/GM-0985.html

7. Brasil. Ministério da Saúde. Portaria GM n. 1.459, de 24 de junho de 2011. Institui, no âmbito do Sistema Único de Saúde - SUS - a Rede Cegonha. Brasília, DF, 2011. [citado 2013 mar. 12]. Disponível em: http://bvsms.saude.gov.br/bvs/saudelegis/gm/2011/prt1459_24_06_2011.html

8. Schneck CA, Riesco MLG, Bonadio IC, Diniz CSG, Oliveira SMJV. Resultados maternos e neonatais em centro de parto normal peri-hospitalar e hospital. Rev Saúde Pública. 2012;46(1):77-86.

9. Stevens G, Miller YD. Overdue choices: how information and role in decision-making influence women's preferences for induction for prolonged pregnancy. Birth. 2012;39(3):248-57.
The variables that require further investigation include directed pushing efforts, use of oxytocin during labor, and management of the perineum. No record is available of either the use of these interventions or their justification, making the analysis of their prevalence in this population problematic. Furthermore, in future studies, the satisfaction of women should also be evaluated.

10. Lobo SF, Oliveira SMJV, Schneck CA, Silva FMBd, Bonadio IC, Riesco MLG. Maternal and perinatal outcomes of an alongside hospital Birth Center in the city of São Paulo, Brazil. Rev Esc Enferm USP [Internet]. 2010 [cited 2013 Mar 12];44(3):812-8. Available from: http://www.scielo.br/pdf/reeusp/v44n3/en_37.pdf

11. Brasil. Ministério da Saúde; Centro Brasileiro de Análise e Planejamento. Pesquisa Nacional de Demografia e Saúde da Criança e da Mulher - PNDS 2006 [Internet]. Brasília; 2008 [citado 2013 mar. 12]. Disponível em: http://bvsms.saude. gov.br/bvs/pnds/img/relatorio_final_pnds2006.pdf

12. Giglio MR, Franca E, Lamounier JA. Avaliação da qualidade da assistência ao parto normal. Rev Bras Ginecol Obstet. 2011;33(10):297-304.

13. Sea-Orchid Study Group; Laopaiboon $M$, Lumbiganon $P$, McDonald SJ, Henderson-Smart DJ, Green S, Crowther CA. Use of evidence-based practices in pregnancy and childbirth: South East Asia Optimising Reproductive and Child Health in Developing Countries Project. PLoS ONE. 2008;3(7):e2646.

14. Shaban IA, Hatamleh R, Khresheh R, Homer C. Childbirth practices in Jordanian public hospitals: consistency with evidencebased maternity care? Int J Evid Based Health. 2011;9(1):25-31.

15. Hodnett ED, Gates S, Hofmeyr GJ, Sakala C. Continuous support for women during childbirth. Cochrane Database Syst Rev. 2012;(10):CD003766.

16. Rocha IMS, Oliveira SMJV, Schneck CA, Riesco MLG, Costa ASC. The partogram as an instrument to analyze care during labor and delivery. Rev Esc Enferm USP [Internet]. 2009 [cited 2013 Mar 12];43(4):880-8. Available from: http://www. scielo.br/pdf/reeusp/v43n4/en_a20v43n4.pdf

17. Alfirevic Z, Devane D, Gyte GM. Continuous cardiotocography (CTG) as a form of electronic fetal monitoring (EFM) for fetal assessment during labour. Cochrane Database Syst Rev. 2006;(3):CD006066.

18. Lawrence A, Lewis L, Hofmeyr GJ, Dowswell T, Styles C. Maternal positions and mobility during first stage labour. Cochrane Database Syst Rev. 2009;(2):CD003934. 
19. Kongnyuy EJ, Mlava G, van den Broek N. Criteria-based audit to improve women-friendly care in maternity units in Malawi. J Obstet Gynaecol Res. 2009;35(3):483-9.

20. Cluett ER, Burns E. Immersion in water in labour and birth. Cochrane Database Syst Rev. 2009;(2):CD000111.

21. Foroughipour A, Firuzeh F, Ghahiri A, Norbakhsh V, Heidari T. The effect of perineal control with hands-on and handpoised methods on perineal trauma and delivery outcome. J Res Med Sci. 2011;16(8):1040-6.

22. Aasheim V, Nilsen AB, Lukasse M, Reinar LM. Perineal techniques during the second stage of labour for reducing perineal trauma. Cochrane Database Syst Rev. 2011(12):CD006672.

23. Khresheh R, Homer C, Barclay L. A comparison of labour and birth outcomes in Jordan with WHO guidelines: a descriptive study using a new birth record. Midwifery. 2009;25(6):E11-8.

24. Lurie S, Kedar D, Boaz M, Golan A, Sadan O. Need for episiotomy in a subsequent delivery following previous delivery with episiotomy. Arch Gynecol Obstet. 2013;287(2):201-4.
25. Carroli G, Mignini L. Episiotomy for vaginal birth. Cochrane Database Syst Rev. 2009(1):CD000081.

26. Bick D, Ismail KM, McDonald S, Thomas P, Tohill S, Kettle C. How good are we at implementing evidence to support the management of birth related perineal trauma? A UK wide survey of midwifery practice. BMC Pregnancy Childbirth. 2012;12:57.

27. Oliveira ASS, Rodrigues DP, Guedes MVC. Percepção de puérperas acerca do cuidado de enfermagem durante o trabalho de parto e parto. Rev Enferm UERJ. 2011;19(2):249-54.

28. Walker D, DeMaria LM, Suarez L, Cragin L, Evaluating Alternative M. Skilled Birth Attendants in Mexico: How Does Care During Normal Birth by General Physicians, Obstetric Nurses, and Professional Midwives Compare With World Health Organization Evidence-Based Practice Guidelines? J Midwifery Womens Health. 2012;57(1):18-27.

\section{Acknowledgements}

To the National Council for Scientific and Technological Development (CNPq), for supporting this research through a Scientific Initiation Scholarship - PIBIC (Process number 115521/2008-9). 